Interfaces

\title{
Text, Image and the Discourse of Disappearing Indians in Antebellum American Landscape Painting
}

\section{Thomas L. Doughton}

\section{(2) OpenEdition Journals}

Electronic version

URL: http://journals.openedition.org/interfaces/323

DOI: 10.4000/interfaces.323

ISSN: 2647-6754

Publisher:

Université de Bourgogne, Université de Paris, College of the Holy Cross

\section{Printed version}

Date of publication: 1 January 2017

Number of pages: 195-222

ISSN: 1164-6225

\section{Electronic reference}

Thomas L. Doughton, "Text, Image and the Discourse of Disappearing Indians in Antebellum American Landscape Painting", Interfaces [Online], 38 | 2017, Online since 13 June 2018, connection on 07 January 2021. URL: http://journals.openedition.org/interfaces/323 ; DOI: https://doi.org/10.4000/ interfaces.323

\section{(c) (†)}

Les contenus de la revue Interfaces sont mis à disposition selon les termes de la Licence Creative Commons Attribution 4.0 International. 


\title{
TEXT, IMAGE AND THE DISCOURSE OF DISAPPEARING INDIANS IN ANTEBELLUM AMERICAN LANDSCAPE PAINTING
}

\author{
Thomas L. Doughton
}

From 1801 through 1835, American Natives - mostly east of the Mississippi or from the Great Lakes and Ohio areas - signed 189 treaties with the Federal Government formally acknowledging appropriation of their lands. But as Georgia Governor Gilmer phrased it in 1830, "Treaties were expedients by which ignorant, intractable, and savage people were induced without bloodshed to yield up what civilized people had a right to possess by virtue of that the Command of the Creator delivered to man upon his formation- - be fruitful, multiply, and replenish the earth, and subdue it."'

Correspondingly, the paintings of the Hudson River School appear at the time of Indian Removal or dispossession of Natives from areas east of the Mississippi and their "resettlement" in "Indian Territory" or Oklahoma. While painters of the School represented doomed Indians in the process of being removed from the landscape - even if part of a natural or organic succession of ages or races, these works are part of the national debate about the Indian. Their work is consistent with national policy demanding their physical removal from homelands east of the Mississippi. Therefore, some Hudson River canvases are documents of the discourse of disappearing Indians, or among visual and literary representations, given synthetic coherence in the 1840 s through the notion of "Manifest Destiny."2

As an ideology of expansionism, however, Manifest Destiny assumed the following: European immigrants had geographical predestination to "possess" the continent; that "according to the intentions of the Creator" the soil was to be "subdued"; that European Christianity was an advanced state of culture destined "to conquer" lower, decadent forms of human organization and that the vast reaches of the continent were under-utilized by transient, marauding, roaming, undeveloped Indians. The significance of Manifest Destiny for aboriginal people was, therefore, clear: Natives had to disappear. Their disappearance or extinction was ordained by the "Disposer of Human Events," the "Author of Nature,"

Journal of the House of Representatives of the State of Georgia $1830,13$.

2 Some scholarship maintains that the destiny of continental domination gains coherence as John L. O'Sullivan first employed the term Manifest Destiny in an editorial in the_New York Morning News,_December 27, 1845. 
the "finger of God," the "Father of the Universe," the "Hand of Nature," or the "Great Engineer of the Universe." How Natives were dealt with politically related to the acceptance of their fated erasure and extinction. As President Andrew Jackson neatly summarized: "Humanity has often wept over the fate of the aborigines of this country," and although Jackson claimed "Philanthropy" had been "long busy employed" in trying to assist the Native "one by one have many powerful tribes disappeared from the earth," with "the extinction of one generation to make room for another." Although tragic, it

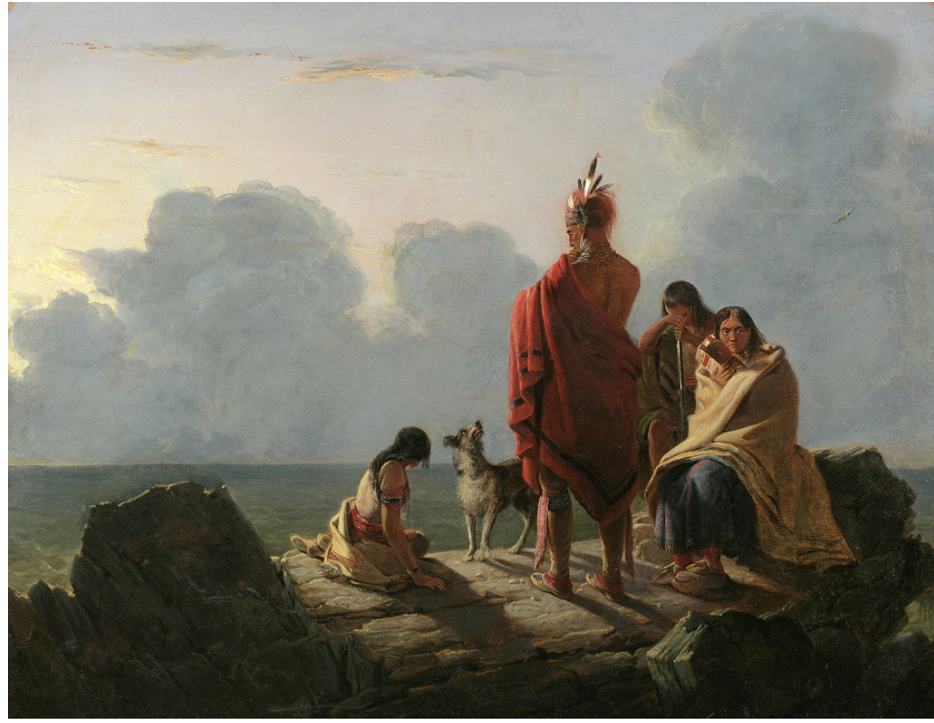

Fig.1. Tompkins Harrison Matteson,"The Last of the Race,” 1847, New-York Historical Society. was the destiny of the Indian to make room for the Europeans. ${ }^{3}$ [Fig.1]

To follow to the tomb the last of his race and to tread on the graves of extinct nations excite melancholy reflections," according to Jackson, but works of the Mound Builders were "the monuments and fortresses of an unknown people, spread over the extensive regions of the West," through which "we behold the memorials of a once powerful race, which was exterminated or has disappeared to make room for the existing savage tribes." Likewise, "the tribes which occupied the countries now constituting the Eastern States were annihilated or have melted away to make room for the whites." As for the "wandering savage" who had not yet "melted away," Jackson asserted governmental policy was "not only liberal but generous;" to save from mingling with the general population, or "perhaps utter annihilation,"

3 Andrew Jackson, State of the Union speech. December 6, 1830. 
government "kindly" offered "a new home" in barren Oklahoma and proposed "to pay the whole expense of his removal and settlement. ${ }^{4}$

Here, then, is an overview of justifications for Indian removal of the 1820s and 1830s. Jackson does not, however, relate that just as the Old Northwest filled with whites, similar population movements occurred in the South: Mississippi admitted to the Union in 1817, Alabama in 1819; and, their combined population of 40,000 in 1810 rising to 445,000 by 1830 .

Nor does Jackson mention white desire for Cherokee lands: an area 200 miles by 215 miles or some 10,000,000 acres, occupied in 1835 by 16,542 Indian residents, 201 intermarried whites, and 1,592 African slaves. The Cherokees also cultivated 44,000 acres, raising over half a million bushels of corn, the "advanced" state confirmed in that of 2,637 households in their territory more than half of these had at least one reader of Cherokee while eighteen percent had an English reader. Nonetheless, Cherokees or others of the so-called "Five Civilized Tribes" were removed from the South to Oklahoma. ${ }^{5}$ Despite opposition to Removal, their territories were seized, ${ }^{6}$ losses of Indian land in the Old South are represented in the accompanying graphic.

Any discussion of the work of the Hudson River painters and Native people also needs to be related to three accompanying contemporary areas of creative production in the antebellum period: (1) a proliferation of various types of printed materials ranging from poetry of authors like William Cullen

4 Ibid.

5 Choctaws between 1831-1834; Chicasaws 1837; Creeks in 1836 and, lastly, the Cherokees between 1838-1839, with some 3,500 of 15,000 Cherokee men, women, and children dying of disease and exposure on the Trail of Tears.

6 A local opponent of Removal was William Biglow. Writing at the time of public controversy concerning "Removal," the first historian of Natick found that "many of the vices both of the savage and civilized state" had led to a virtual disappearance of "the tribe of Aborigines which was first civilized and Christianized in North America, by Protestant missionaries ... similar the fate of most, if not all the tribes in New England. He speculated, "Whether a better destiny awaits the Red Men of the south and west, is known only to Him, who created them. The prayer of every Christian, of every philanthropist must be, Lord, have mercy on them, and protect them from their adversaries - Lord, have mercy on their persecutors, and touch their hearts with feelings of humanity, of pity and of justice." See Biglow, Natick History, 84, a text which appeared in 1830, one year before "The Cherokee Nation v The State of Georgia" came before the U.S. Supreme Court (1831), the Court rejecting Cherokee standing in its appeal to the Court, paving the way for "Removal" of the "Civilized" Tribes. 
Bryant, novels of James Fennimore Cooper and others, captivity narratives, dramas on King Philip and other eastern Indians, and a flood of town histories in the Northeast chronicling the demise and disappearance of Indians; [2] efforts of Catlin, King, Bodmer, Wimer and other artists to document and record visually a vanishing people; and, [3] historical paintings depicting conquered, vanishing and disappearing Indians. Together, they constitute what, for lack of a better term, I have written about as a discourse of disappearing Indians. [Fig.2]

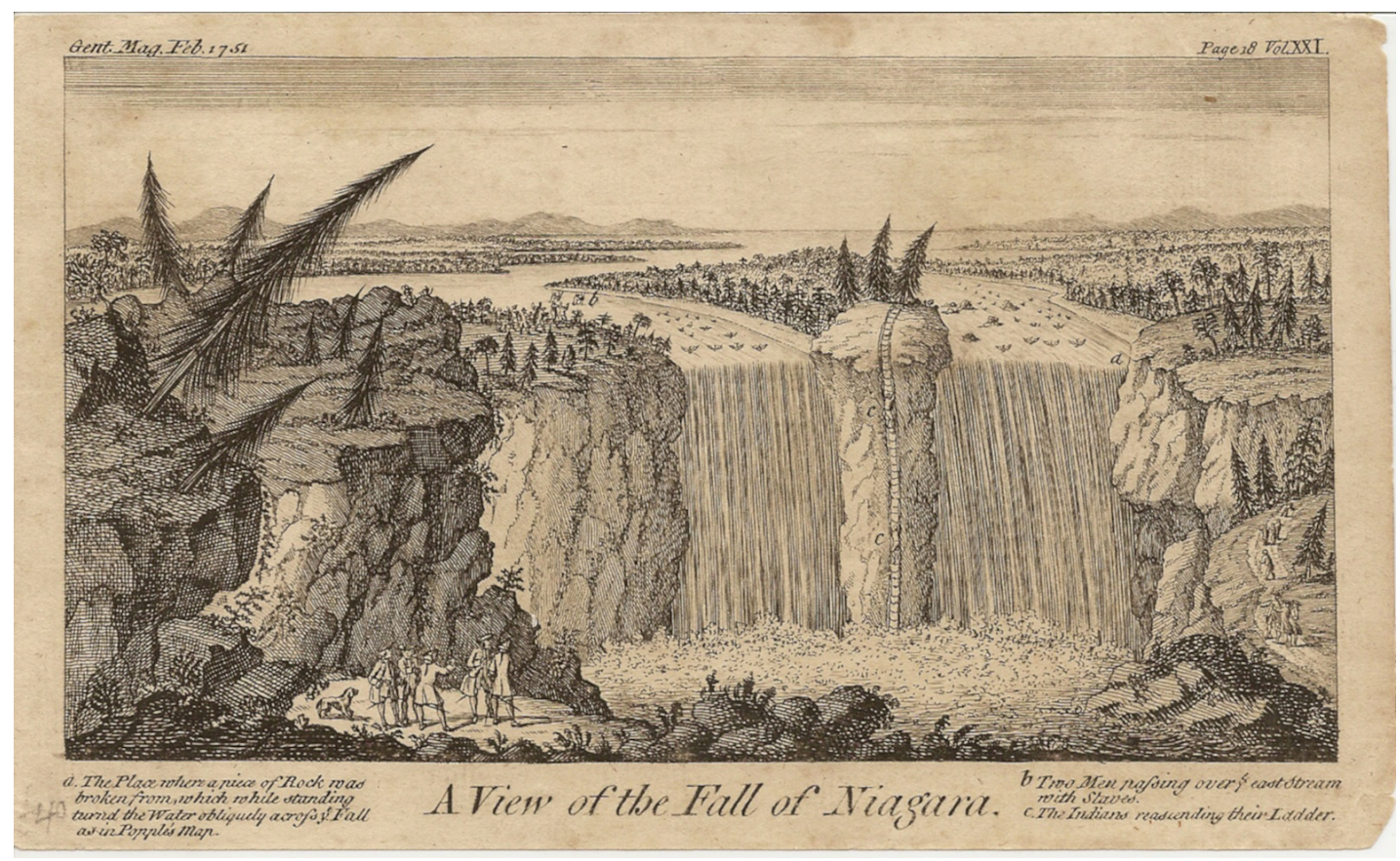

Fig.2. From The Gentleman's Magazine, published in London in 1751. 
However it is to be labelled, this imagining of Indians as doomed to extinction does not arise with Manifest Destiny in the nineteenth century. Rather, it is embedded at the heart of the historiography of the American experience. According to the scenario established at the beginning of the Euro-American "errand" into the wilderness, Massachusetts Native people were nearly "wiped out" in the virgin soil epidemic of 1618-19, called a "wonderful plague" destroying them and leaving their lands free for occupation. The epidemic on the eve of English immigration to New England was the means chosen by Jehovah to make room for building the new Jerusalem. "Disappearing" Indians are thus first encountered in the works of the seventeenth-century Massachusetts writers, remaining a persistent presence of an absence at the center of the American mythology of progress and manifest destiny. In outline, seventeenth-century writers inform: Massachusetts Natives did not enclose their land, therefore, their lands were not really their property; Indians had more land than they needed or knew how to use; they welcomed the coming of Europeans; and, epidemics and pandemics prior to 1620 and, again, in 1633-34, were proof Jehovah was clearing the "uncouth" and "heathen" wilderness to make way for his saints. Indians were, simply, doomed to disappear. Therefore, their disappearance is central to the vision of New England codified in the region's earliest narratives.

What is advanced in these early works is the notion "And, then, there were none," as Massachusetts Indians of the time of Contact disappeared. Additionally, Native casualties in the socalled King Philip War of 1675-1676 allowed whites to imagine surviving Native populations that were killed off or vanished. By the nineteenth century, however, disappearing or vanishing Indians became thoroughly enmeshed in prolongation of one of the "grand themes" of U.S. history: the struggle between savagery and civilization. ${ }^{7}$

For example, Neal E. Salisbury, Conquest of the "Savage": Puritans, Puritan Missionaries, and Indians, 1620-1680 (Ph.D. diss., University of California, Los Angeles, 1972 ); Manitou and Providence: Indians, Europeans, and the Making of New England, 1500-1643 (New York: Oxford University Press, 1982); Richard Slotkin, Regeneration Through Violence: The Mythology of the American Frontier, 1600-1860 (Middletown, Conn.: Wesleyan University Press, 1973); Brian W. Dippie, The Vanishing American: White Attitudes and U.S. Indian Policy (Middletown, Conn.: Wesleyan University Press, 1982); Richard Slotkin and James K. Folsom, So Dreadfull A Judgment: Puritan Responses to King Philip's War, 1676-1677 (Middletown, Conn.: Wesleyan University Press, 1978); and, Michael J. Puglisi, The Legacies of King Philip's War in Massachusetts Bay Colony, (Ph.D. diss., College of William \& Mary, 1987), particularly, Chap. I: "Punishment and Repentance," 7-37; Chap. II: "The Victors and the Vanquished," 13, 18-19, 20-21, 29, 38-75; also conflict with Indians is identified among "anxieties" related to Massachusetts witchcraft scares, John Putnam Demos, Entertaining Satan Witchcraft and the Culture of Early New England (New York: Oxford University Press, 1982) 379-381. 
According to historian Robert Berkhofer, New England had "far excelled" other regions in the production literary texts-journals, chronicles, promotional tracts, sermons and histories - articulating an opposition between "Friend Indian" and "Enemy Indian" or what he calls "the paradigm of polarity" through which occurs "the imaginative transformation of the Native American from the Indian of Contact into the Indian of symbol and myth." ${ }^{8}$ What resulted was a topology of good Indians, bad Indians, and debased or degraded Indians. To these three groups described by Berkhofer, however, should be added a fourth stereotype: the already disappeared or vanished Indian. Does this typology of good, bad, degraded or disappeared Indians have relevance for the Hudson River School? I would maintain that popularly accepted images of Native people of the antebellum period are reflected in the work of this school. To the question whether Cole, Duncanson, Durand, Gifford and others intended their depictions of Indians as part of a cant of conquest and site of expansionist ideology, any response would have to be more tentative. [Fig. 3]

Still their work,
nonetheless, mirrors and
reinforces popularly accepted notions of Indian disappearance. Often a lone Native or a pair of lonely Indians, appropriately miniaturized in the foreground, survey panoramic landscapes. Examples include: "Catskill Mountain Scenery" by Kensett; "Falls of the Sawkill" by William J. Bennett, engraved by Asher Durand; and Sanford Gifford's "Mount Mansfield Vermont." Additionally, Cole

8 Berkhofer, White Man's Indian, 80-81; 28-30.

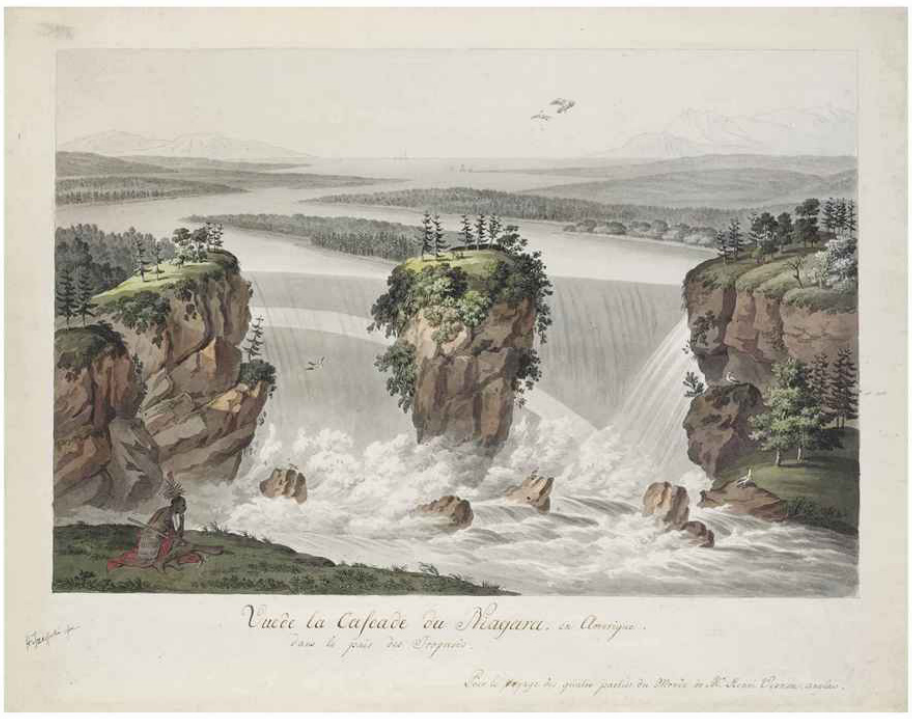

Fig. 3. After Henry Fuesli, Vue de la Cascade du Niagara, en Amerique. dans le pais des Iroquois... engraving Pour le Voyage des quatre parties du Monde de M. Henri Vernon. 
painted lone or lonely Indians in "View of Lake Winnispiscogee," "Distant View of Niagara Falls," and the small canvas part of the Hudson River exhibition. ${ }^{9}$

The close association of Hudson River School artists and contemporary poets is clearly represented in Asher Durand's familiar painting Kindred Spirits, which shows Cole and William Bryant Cullen on a promontory overlooking a typical landscape. Relationships between the visual imagery of the School's painters and the work of writers manifest themselves in several ways.

On the one hand, Hudson River School artists repeatedly turn to the printed word—of poems, novels, and historical texts in selecting sites to be painted, in many instances their carefully crafted landscapes thematically dependent upon local legends and historical associations. Mounts Chocurua in New Hampshire, Katahdin in Maine and Mansfield in Vermont are, for examples, frequently painted by Hudson River artists for both natural beauty and connection to Indians, as established by various written works. Correspondingly, some artists like Asher Durand, for example, are also actively involved in illustrating literary texts.

On the other hand, as early as 1819 Washington Irving, for example, informed his readers that his craft was akin to the painters when in one of pieces in The Sketch Book he calls himself "Geoffrey Crayon." (vii) and Cole, wrote to Daniel Wadsworth: "I still look forward with hope to the time when I shall be able to produce pictures that shall affect the mind of the beholder like the works of a great poet - that shall elevate the imagination and produce a happy moral effect." ${ }^{10}$ [Fig. 4]

The connection of Hudson River artists and writers is also confirmed in personal relationships between individual painters and poets, novelists and historians, such as the celebrated example of the

9 Kensett's "Catskill Mountain Scenery," engraved by H. Beckwith, was reproduced in A Landscape Book by American Artists and American Authors 30-31, to illustrate Bryant's "Catterskill Falls"; Bennett's "Falls of the Sawkill," was reproduced in William Cullen Bryant, The American Landscape, No. 1 [shortened title] (New York: Elam Bliss, 1830) while Gifford's "Mount Mansfield Vermont" is reproduced in McNulty, ed., The Correspondence Thomas Cole \& Daniel Wadsworth. Thomas Cole's "View of Winnipiscogee" is also reproduced in The Correspondence; his "Distant View of Niagara Falls" is in the collection of Chicago Art Institute.

10 James T. Callow, Kindred Spirits Knickerbocker Writers and American Artists 1807-1855, hereafter cited as Kindred Spirits (Chapel Hill: University of North Carolina Press, 1967) vii; J. Bard McNulty, ed., The Correspondence of Thomas Cole and Daniel Wadsworth: Letters in the Watkinson Library, Trinity College, Hartford, and in the New York State Library, Albany, New York (Hartford: Connecticut Historical Society, 1983) xix 


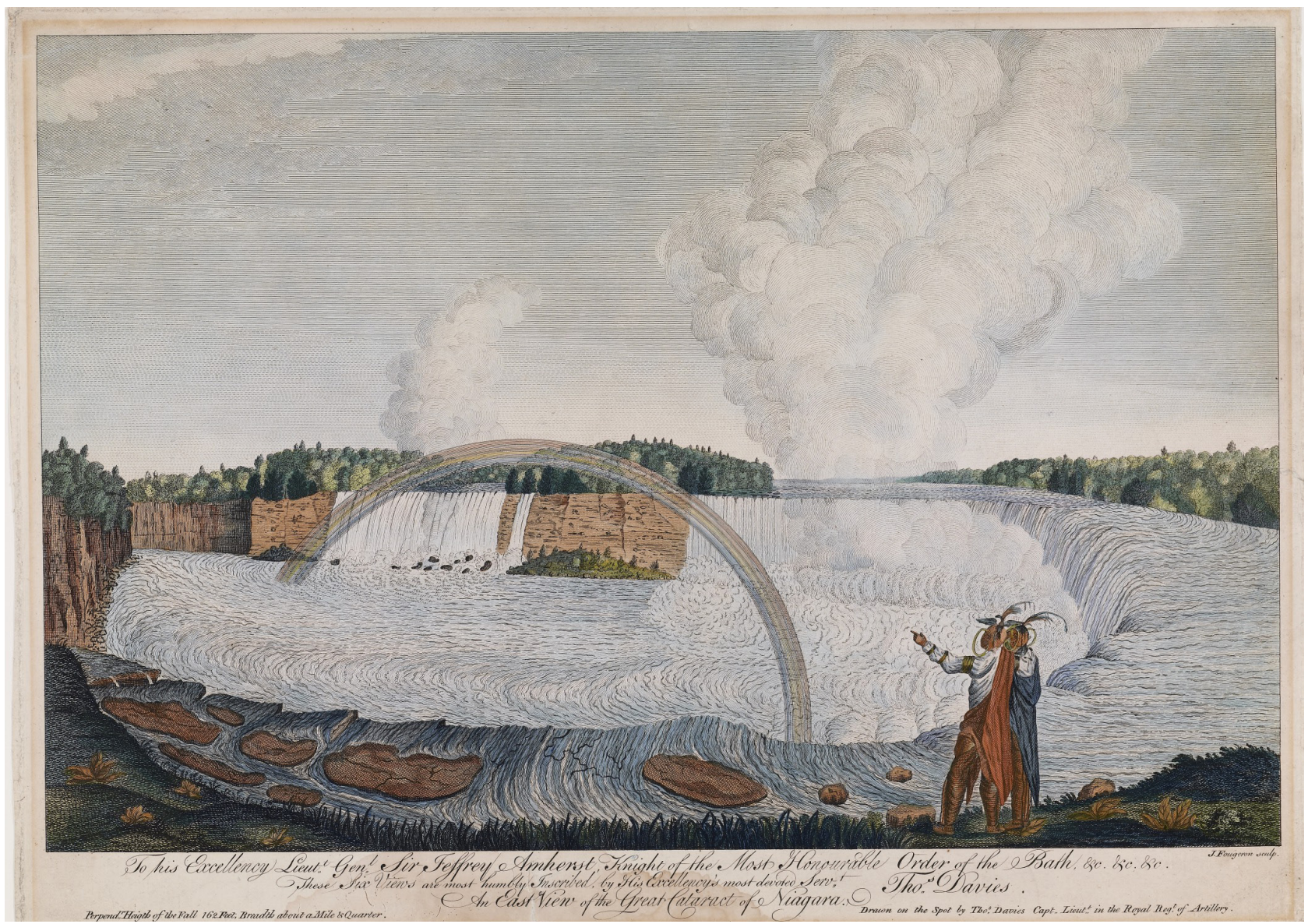

Fig. 4. An East View of the Great Cataract of Niagara, c. 1768, an engraving of Thomas Davies, Royal Ontario Museum, Toronto. 
friendship of Cole and Cullen. The results, however, include uncertainty or instability in representation of Native peoples. The instability in the iconography of the Indian is mirrored in various, sometimes seemingly contradictory literary works - part of the discourse of disappearing Indians. On the one hand, some opinion makers of the Early Republic imagined Indians as if classical heroes, much as Benjamin West exclaimed in 1760 at Rome on first seeing the Belvedere Apollo: "My God, how like it is to a young Mohawk warrior." 11 In this modification of the Indian as noble savage, as critic David Lubin commented, in a "dialectical reversal of the wildman" or a libidinous sensualist the Native becomes a paragon of self-restraint, dignity and genuinely, inviting comparison to the world of classical civilization familiar to educated Americans. While as early as the seventeenth century representations of the Indian invited comparison with hellenistic statuary, the neoclassical and later Romantic construction of the Indian as nature's true child allowed Indians to be imagined "the reincarnation of antique civilization, with its hypostatized beauty, nobility and simplicity." 12

Writing in the North-American Review in 1815, William Tudor maintained "Aborigines" or Indians first encountered by Europeans "possessed so many traits in common with some of the nations of antiquity, that they perhaps exhibit the counterpart of what the Greeks were in the heroick age, and particularly the Spartans during the vigour of their institutions." 13

Even the previously demonized King Philip begins to be covered by a classical "cloak," his rehabilitation accomplished in later stage works including Metamora. For poet Sprague, Philip is heroic:

Even that he lived, is for his conqueror's tongue

By foes alone his death-song must be sung;

No chronicles but theirs shall tell

His mournful doom to future times;

May these upon his virtues dwell,

And in his fate forget his crimes

As final example, in his Book of Indians, Samuel G. Drake, offered the following version of

11 John Galt, The Life of Benjamin West ed. by Nathalia Wright, 105.

12 See David M. Lublin, Picturing A Nation, 31-32.

13 Tudor, "Phi Beta Kappa Address," 19. 
Philip's death through an anonymous verse:

He felt his life's blood freezing fast

He grasped his bow, his lance, and steel

He was of Wampanoag's last.

To die were easy - not to yield.

His eyes were fixed upon the sky

He gasped as on the ground he fell

None but his foes to see him die-

None but his foes his death to tell

Examples of noble, heroic Indians in works of poetry, fiction and drama of the antebellum period abound. Yet at the same time other works recapitulated images of bad or debased Indians. [Fig.5]

Between 1824 and 1834 were published some forty novels with Indian characters or episodes describingnatives.AshistorianBerkhofer explained the good Indian, as represented by Massasoit and Squanto, was constructed in imaginations as "friendly, courteous, and hospitable" so long as "obligations" are honored; he was characterized by "handsomeness of physique and physiognomy," and endowed with "great stamina and endurance"; he was "modest in attitude," exhibiting "great calm and dignity in bearing, conversation," even when tortured; and, he was "brave in combat ... tender in love

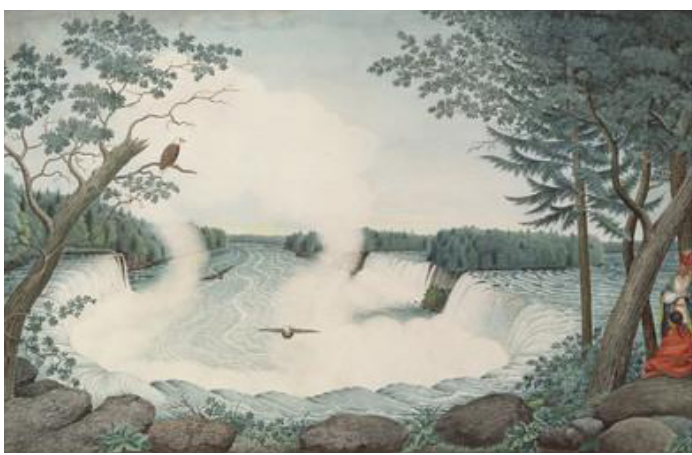

Fig. 5. Thomas Davies, Niagara Falls From Above, circa 1762-68. for family and children" while priding himself on "independence ... with a plain existence and wholesome enjoyment of nature's gifts," living a "life of liberty, simplicity, and innocence." Another historian claimed that good Indians were essentially white. ${ }^{14}$

14 "What tied the stories of these virtuous Indians together was that for such figures to be seen in this light, they generally had to act against the best interests of their own people ... This elevation saw the actual histories of these figures replaced by mythic narratives depicting the crucial moments when aid was given to the whites, such as the first Thanksgiving dinner in New and the saving of John Smith," see Robert S. Tilton, Pocahontas: The Evolution of an American Narrative (Cambridge: Cambridge University Press, 1994) 174. 
Correspondingly, for Berkhofer, the bad Indian was imagined living in nakedness, lechery, passion, vanity, polygamy, promiscuity, constant warfare, and fiendish revenge in such a way that when his habits were not barbarous, he remained "loathsome" to Euro-Americans; "cannibalism and human sacrifice were the worst sins," followed by a repulsive diet he enjoyed; his other traits included "indolence rather than industry, improvidence in the face of scarcity," thievery, treachery, and superstition which substituted "license for liberty, a harsh lot for simplicity, and dissimulation and deceit for innocence."

A third image, the degraded Indian, was constructed particularly in the late eighteenth and early nineteenth centuries from an assumption that Indianness and civilization were "inherently incompatible," much as Berkhofer continued that "Indians who remained alive and resisted adoption of civilization appeared to accept White vices instead of virtues and so become those imperfect creatures, the degraded or reservation Indians." Represented as "degraded, often drunken ... neither noble nor wildly savage but always scorned," Natives were "degenerate and poverty-stricken ... unfortunates ...presumed to be outcasts from their own race, who exhibited the worse qualities of Indian character with none of its redeeming features." To these three images detailed by Berkhofer can be added a fourth representation: the vanished or already disappeared Indian. Almost all assuming the disappearance of Native people, creative literary works of the antebellum period, accordingly, draw upon socially acceptable constructions of the Indian. [Fig. 6]

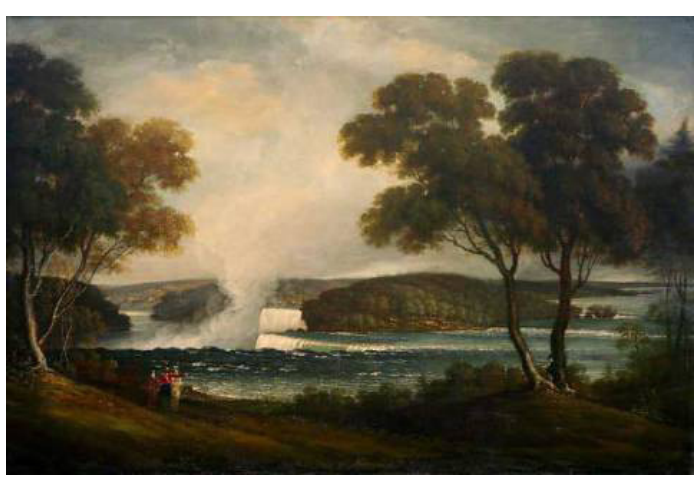

Fig. 6. The Horseshoe Fall from Below Table Rock, attributed to John Vanderlyn.

While artists of the first generation of

Hudson River School labored, primarily in the Northeast, their work was part of a more generalized depiction of Indians for the antebellum American public: documentary representation of a doomed race and the celebration of their disappearance through historical painting. According to Matthew Baignell, depictions of Natives in this period are related to "rhetoric of American individualism, selfreliance, providential protection, middle-class morality, and the establishment of a nation of continental dimensions," revealing "racist and imperialist subtexts." Artists producing these works were "coopted by 
the prevailing ideology, public policies and popular beliefs," their output recording "the racial theories and territorial imperatives" as well as the history of nation-building, individuals "enmeshed in the discourse of power"; for Baignell, providing "at least as much cause for embarrassment as for celebration." 15

In the text produced for America as the West, William Truettner wrote that historical scenes collapse time, redefining the past as orchestrated by patrons and the acceptance of expansionist ideology, with patrons informing artistic interpretation of westward movement, and encouraging subjects suitable for the ideology's needs. Yet, in this work is an obvious contradiction between frequently large canvases claiming to chronicle an expanding democratic society while at the same time expressing the requirements of Manifest Destiny dispossessing Indians, who were not extended the rights of the United State citizenship until the 1920s. One remarkable aspect of these works is an effort to decontextualize actual history in order to use the Indian in an "official" discourse of his or her disappearance. A certain trajectory shapes and orders individual works into an assemblage of visual imagery glorifying expansionism. The components, sites of Indian undoing and disappearing, reflect the "official, standard" iconography of American democracy in the antebellum period: the "discovery" of the Americas; selected events in the exploration of North America, the most frequently represented scenes involving La Salle or De Sota; the arrival of "our" ancestors and founding of British colonies; "peopling" of America and overcoming the Indian in the eighteenth century; the struggle for "independence" and founding of the Republic; and, the movement of "civilization" across the Alleghenies to the Old Northwest, the Southwest and Missouri. Over and over again were painted scenes of the arrival of Europeans in the New World. Indeed, the U.S. Capitol would, by mid-century, become a repository for many of these images. Of the eight monumental canvases in the Rotunda, three represent historical encounters with Natives: Chapman's baptism of Pocahontas; William H. Powell's “Discovery of the Mississippi;" and the landing of Columbus at Guahanana or San Salvador by Vanderlyn. A large Bierstadt painting, "Discovery of the Hudson River," is in the House of Representatives Wing and nine painted scenes of Indians by Seth Eastman were commissioned for the Capitol. Natives are also depicted in nine sculptures part of the frieze beneath the Rotunda's dome. The Rogers Doors or bronze doors at the East Rotunda Entrance include three scenes with Natives: departure of Columbus from Palos, his landing in the New World and his first meeting with Indians. In the 1850s two busts of Chippewa Indians were placed in the building. Additionally, until its removal to the Smithsonian

15 Matthew Baignell, "Territory, Race, Religion Images of Manifest Destiny,” 20. 
in 1976, Greenough's "The Rescue" adorned the eastern steps leading up to the Capital. ${ }^{16}$ There can be demonstrated an "upward movement" from discovery by Columbus through exploration of La Salle at the Mississippi River to the founding colonies and events leading up to the Revolution: and eventually, through a movement across the Mississippi to the Great Plains in a pictorial march across the continent. Little reflection seems to be given the contradiction between justifying liberty on behalf of an expanding democratic society while dispossessing the Indian in the name of Manifest Destiny utilizing themes that resonate in these visual works: collapsed time, redefinition of past as orchestrated by patrons and

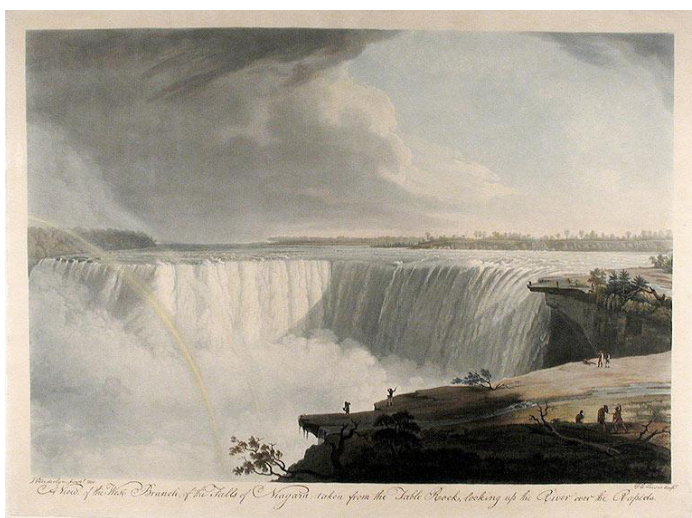

Fig. 7. Alvan Fisher, A General View of the Falls of Niagara, 1820, Smithsonian American Art Museum, Washington, D.C. expansionist ideology, artistic interpretation of westward movement. They represent a contradiction: justifying liberty on behalf of an expanding democratic society while dispossessing the Indian in the name of Manifest Destiny. [Fig. 7]

Occasionally works by Cole, for example, are consistent in depicting scenes with Indians as in three representations of Niagara Falls: Horseshoe Falls from Canada Side, c. 1829-30, with a lone Indian on a promontory in front of the falls; View of Niagara Falls, from 1829; and, Niagara Falls, 1830 , with Indians on promontory at the center foreground of the canvas. Additionally, an engraved view of Niagara Falls by Cole was one of the most widely disseminated images of the cataracts during the nineteenth century, both in England and in the United States. In selecting the Falls, Cole reflects

16 See Art in the U.S. Capitol, 134-135, 140-141, 185-193, 216, 304-311, 343-347. The three works with Natives in the Rotunda are displayed with representations of "great events" of American history: Robert Weir's "Embarkation of the Pilgrims at Delft Haven Holland July 2nd, 1620;" and Trumbull's "The Declaration of Independence," along with "George Washington Resigning His Commission of Congress as Commander in Chief," Burgoyne's surrender at Saratoga and the surrender of Cornwallis at Yorktown. The works by Eastman depicting various aspects of Native life were moved from the Capitol to the Longworth Office Building. Marble busts by Francis Vincenti of Chippewa chiefs Aysh-ke-bah-ke-ko-zhay and Beeshekee were acquired in 1854 and 1858. As part of the Rotunda frieze begun later in the century by Constantino Brumidi and finished, after his death by Filippo Constaggini, were the following scenes incorporating Indians: the landing of Columbus; entry of Cortes into the Hall of Montezuma; Pizarro's conquest of Peru; midnight burial of De Soto; Pocahontas saving Capt. John Smith; the landing of the Pilgrims at Plymouth Rock; Penn's 1682 treaty with Indians; making the peace treaty by Georgia Governor Oglethorpe with southeastern Indians; and, lastly, the death of Tecumseh in 1813 at the Battle of the Thames. The bronze Rogers Doors include among panel images the departure of Columbus and his first meeting of Indians while the tympanum represents the landing of Columbus in the New World. 
the contemporary acceptance of watercourses-particularly, cataracts or waterfalls - as the "voice of the landscape," and anchors these canvases in an earlier style of representing Niagara Falls - with one scholar finding that "more than just a realistic documentary touch," the Indian "serves symbolic and aesthetic functions" in these paintings, emphasizing the exotic wonders of the American wilderness and also "serving as a symbol for the hugeness of wild America." 17

Starting in the eighteenth century, the Falls were recognized as one of the wonders of North America and in frequent depiction served as a symbol for the immensity of the American wilderness, one study reproducing nine images painted of Niagara from 1768 through 1830. Natives are represented in each of these works, ${ }^{18}$ although some artists, like Trumbull, will sometimes include Natives in Niagara

17 Cole's images include: Horseshoe Falls from Canada Side, oil on canvas, Collection Cranbrook Academy of Art; View of Niagara Falls, oil on wood, George F. McMurray Collection, Trinity College, Hartford, Connecticut; and Niagara Falls oil on canvas, Chicago Art Institute. All are reproduced in Elizabeth R. McKinsey, Niagara Falls: Icon of the American Sublime, 204, 206, 207, 231; for quotation, Ibid., 21. For other texts discussing Niagara as symbol and object of representation in this period, also see: George A. Seibel, Three Hundred Years Since Father Hennepin: Niagara Falls in Art, 1678-1978, [Niagara Falls, Ont.: Niagara Falls Heritage Foundation, 1978]; Jeremy E. Elwell, Niagara: Two Centuries of Changing Attitudes, hereafter cited as Niagara, Two Centuries, (Washington, D.C.: Corcoran Gallery of Art, 1985).

18 An East View of the Great Cataract of Niagara, c. 1768, an engraving of Thomas Davies, Royal Ontario Museum, Toronto, represents two Indians in the foreground viewing the Falls. Niagara Falls from Below, c. 1766, watercolor by an unknown British artist, New York Historical Society, with two soldiers referencing the British garrison nearby shows two groups of Indians in the foreground: two Indian women, and two Indian men. The Falls of Niagara, c. 1783, an engraving by James Heath, Rare Book Room, Buffalo \& Erie County Public Library, depicts a group of whites and an Indian pointing towards the cataracts. View of Niagara Falls, c. 1776, an etching and watercolor by H. Fuessli, Royal Ontario Museum, shows the Falls with a lone Indian, copied from West's Death of Wolfe, seated in the left foreground. View of the Horse Shoe Fall of Niagara, c. 1799, engraving by Isaac Weld, reproduced in Travels Through the States of North America in 1795, 1796, and 1797, depicts three Indians on a rock, at center foreground, before the Falls. The Falls of Niagara, c. 1800, an etching, Print Collection, New York Public Library: Astor, Lenox and Tilden Foundations, shows a Native couple seated on a fallen $\log$, in the foreground, with their backs to the Falls. Science Unveiling the Beauties of Nature to Genius at America 1814, gouache, by John James Barralet, Print Collection New York Public Library, includes a kneeling Indian woman with pappouse at the feet of Science. A Symbol of America, 1800, engraving by P. Stampa, was published in London in 1800 to commemorate the death of Washington in the previous year; in this work "Columbia" leans on Washington's gravestone, the Falls in the background, wild pines beside it, two Indians fishing while an Indian boy with feathered headress, looking like a putto or cherub also leans, right foreground, on the gravestone. In 1801, Michel-Guillaume Saint-Jean de Crevecoeur produced two engravings of the Falls: Vue d'une partie de la Branche Orientale de la Cataracte de Niagara with a lone Indian perched on rock, and Vue d'une partie des deux Branches de la Cataracte de Niagara, with a Native group in the foreground towards whom advances another unclothed individual, see Lane, 36-37. And, in the last example, Alvan Fisher's A General View of the Falls of Niagara, 1820, oil on canvas, National Museum of Art, Smithsonian, Indians in the right foreground are seated on a fallen pine near standing whites. For images other than works already cited in this note, see McKinsey, Niagara Falls, 19-20, 22, 24, 45, 71, 99, 103 
landscapes, at others times omit the same Indians. ${ }^{19}$

Interestingly, subsequent artists associated with the Hudson River School like Regis Gignoux, Crospey, Kensett, Church and Bierstadt painted the same Niagara Falls, but with Indians absent from their works. ${ }^{20}$ [Fig. 8]

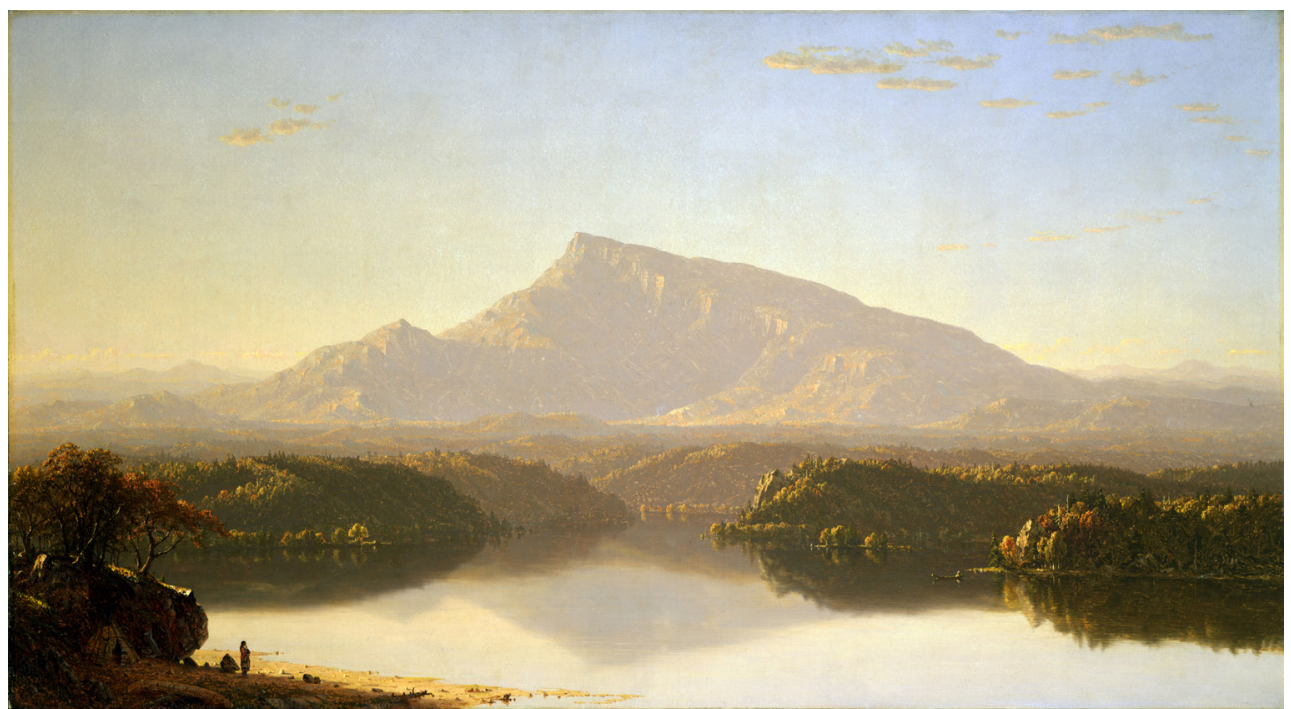

Fig. 8. Sanford Robinson Gifford, Wilderness, view of Mount Chocurua, (1861), Toledo Museum of Art, Toledo, Ohio.

19 In 1807, Trumbull painted Niagara Falls from an Upper Bank on the British Side [Wadsworth Atheneum], Niagara Falls from Below the Great Cascade in 1808 [also Wadsworth Atheneum] and a second image from 1808, Niagara Falls from Two Miles Bellow Chippawa [New York Historical Society], all without Indians, however, his Niagara Falls under Table Rock [New York Historical Society], depicts a group of Indians near a Plains teepee in the left foreground toward whom what appears to be an unclothed Indian is advancing. Trumbull's Niagara paintings are all reproduced in Adamson, Niagara, Two Centuries, 28-31.

20 Gignoux's Niagara in Moonlight, reproduced in Harper's Weekly, July 9, 1859; Cropsey's Niagara Falls, 1868, oil, Amherst College, and Niagara Falls from the Foot of Goat Island, 1857, oil, Museum of Fine Arts Boston; Kensett's Niagara Falls, 1851, oil, Amherst College, along with Niagara Falls, c. 1851, Denver Art Museum, and Whirlpool, Niagara, c. 1851-2, MFA Boston; Frederick Church, Falls of Niagara, 1867, National Galleries of Scotland, Edinburgh; and, Bierstadt, Niagara from the American Side, n.d., MFA Boston. 
For Cole, however, much of North America "rested in the shadow of primeval forests, whose gloom was peopled by savage beasts, and scarcely less savage men." 21

\section{The Crayon (1858) informed:}

Soon the last red man will have faded from his native land, and those who come after us will trust to our scanty records for their knowledge of his habits and appearance ... Setting aside all the Indian history of the West, how much there is that is romantic, peculiar, and picturesque in his struggles with civilization in our section of the country ... As an accessory in the landscape the Indian may be used with great effect. He is at home in every scene of primitive country.

Before works of the Hudson River School painters and others, the "wildness" of the American landscape was considered an obstacle or deficiency in intellectual assimilation of European aesthetic canons. The continental doctrine of "association" was inimical to the American topography in that "association" defined the ideal landscape with ruins, relics, myths and legends that assumed a uniformed "past" of humanity; simply, America lacked materials required by "association."22 In disagreement, Cole, for example, maintained in his "Essay on American Scenery" that "American scenes are not destitute of historical and legendary associations; the great struggle for freedom has sanctified many a spot, and many a mountain stream and rock has its legend, worthy of a poet's pen or painter's pencil."23

Nonetheless, nineteenth-century New England, across works of history, fiction and reportage was created and solidified an obstinate discourse of disappearing Indians that claimed aboriginal people had already vanished or were doomed to disappear. At times contradictory, if not duplicitous, this discourse was, on the one hand, an attitude of the dominant culture toward New England's past, imagining that Indians had become "extinct." On the other hand, it is an ideology of vanishing Indians that refused to "see" the continued presence, persistence and survival of the region's nineteenth-century

21 "A very few generations have passed away since this vast tract of the American continent, now the United States, rested in the shadow of primeval forests, whose gloom was peopled by savage beasts, and scarcely less savage men...," Thomas Cole, "Essay on American Scenery," 4-5, 7-8.

22 See Richard Van Zandt, cited xiv-xv.

23 For this frequently cited passage, see Thomas Cole, "Essay on American Scenery," American Monthly Magazine, 1 (January 1836), 2. 
Natives. In countless town chronicles, newspaper articles, fictional treatments and poetic works-all reinforced through a visual iconography-New England Indians took on the presence of an absence. Natives became "people without history," people without "a place," absent from the social landscape, their collective identity as Native, in both past and present, "erased." [Fig. 9]

Echoing comparable sentiments Judge Joseph Story, for example, inquired, "what can be more melancholy than their history?" At a commemoration of the town's founding in 1835, Story explained

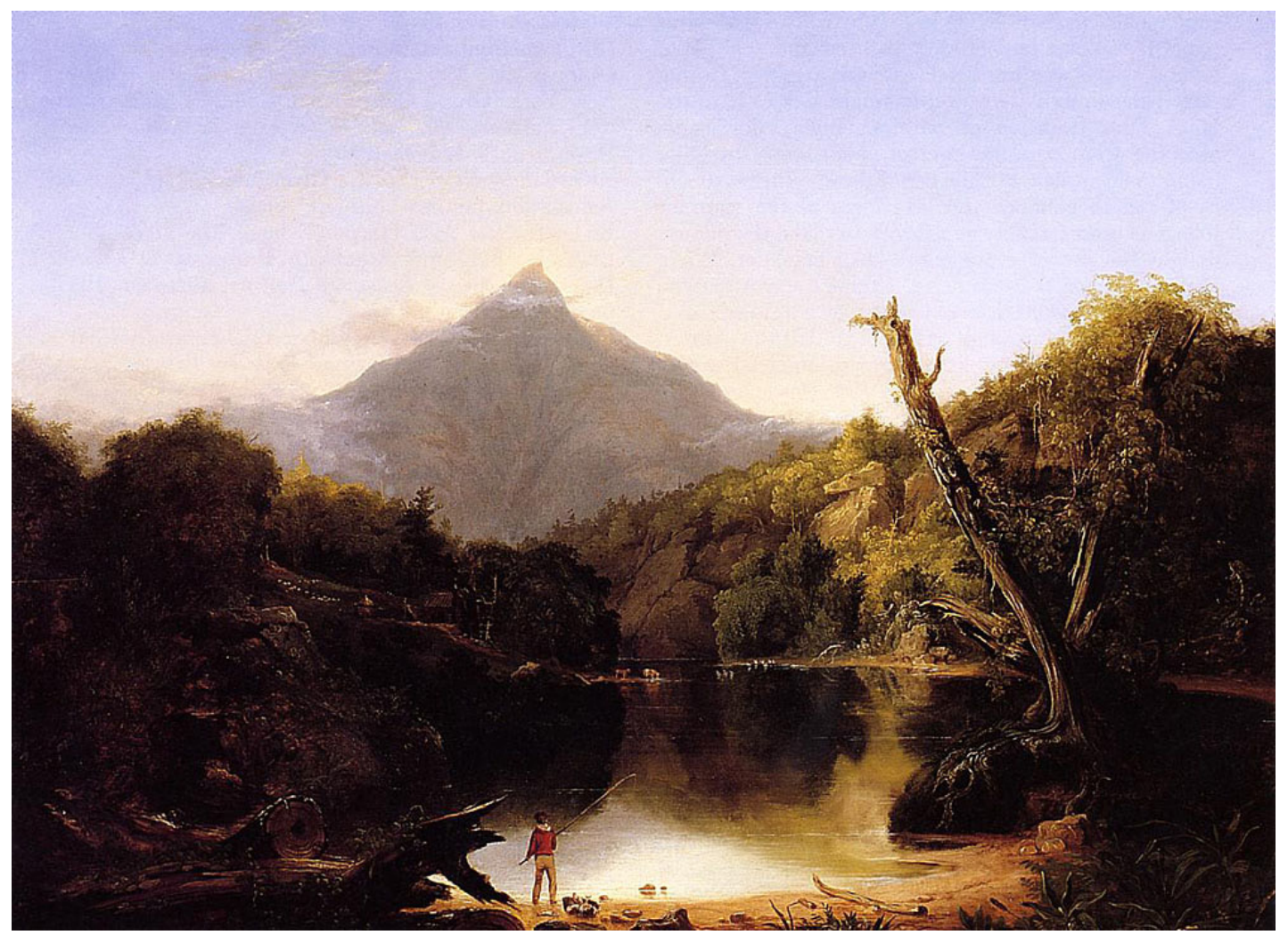

Fig. 9. Thomas Cole, Mount Chocorua, New Hampshire, 1827, Private Collection. 
to Salem residents that "By a law of their nature, they seem destined to a slow, but sure extinction. Everywhere, at the approach of the white man, they fade away. We hear the rustling of their footsteps, like that of the withered leaves of autumn, and they are gone for ever. They pass mournfully by us, and they return not." 24 In these opinions, it could be argued that Story, likewise, reflects the general attitude of thinking New Englanders of his period.

The year following his Salem oration, Story wrote to his son that he was reading Irving's Life of Columbus, which "proves, and sadly proves (what I have ever believed) that the Europeans were always the aggressors of the natives in America, in all their contests, and that the sins of all the murders and desolations on these shores are attributable to their baseness and avarice and detestable passions," claiming, "I never think on the subject without bitter regrets and undisguised indignation." The same letter contained the following sentiments:

The poor Indians! They will soon be exterminated in Florida, where the war is now waging. On their part it is now a desperate struggle for existence; and I have no doubt but they will all perish in the contest. In the course of a few years, not a relic will be found in all America of this heroic race. Their history will be lost in uncertain traditions. The white man will tell the story of their disappearance in his own way. ${ }^{25}$

Works of local historians reflect aspects of the "Indian Question" that haunts the early Republic. In local writings the Question animates several discussions advanced at differing periods of the last century, concerning:

24 Brian Dippie, The Vanishing American, 1.

25 Joseph Story, "Discourse, Pronounced at the Request of the Essex Historical Society, Sept. 18, 1828, in Commemoration of the First Settlement of Salem," 80; Story to William W. Story, Feb. 21, 1836 in William W. Story, ed., 2: 229. For a summary of Story's life and works, see entry by Paul Finkelman, in John A. Garraty and Mark C. Carnes, eds., American National Biography hereafter cited as ANB (Oxford: Oxford University Press, 1999) 20: 889-893. Judge Story (1779-1845) was a son of an early patriot, who was one of the Sons of Liberty participating at the Boston Tea Party and who served in the Continental Army. During his long career, the younger Story was a U.S. Supreme Court justice, legal scholar, congressman, and professor of law at Harvard. According to Paul Finkelman, for example, "growing up in the aftermath of the Revolution, Joseph absorbed from both of his parents republican values, Unitarian theology, a heritage of Puritan idealism, a fierce sense of nationalism, and an unbending dedication to public service." 
- the "origin" of Indians, whether they were "Asiastic" people who migrated to the New World, or a lost tribe of Israelities, and whether there were connections between aboriginal peoples of North and South America;

- the "pre-history" of Natives or whether a supposedly racially distinct advanced and sophisticated people were conquered and displaced by less developed savages encountered by Europeans;

- the "present" or "nature" of the savages and "children of the forest" or whether Indians could be civilized, Christianized and converted from "roving bands of barbaric nomads" to settled, sedentary farmers; and,

- the "future" of the Natives whether they were "fading" through operation of impersonal biological laws, to be "exterminated" to make room for Euro-Americans or to be "removed" to specifically designated Indian residence areas.

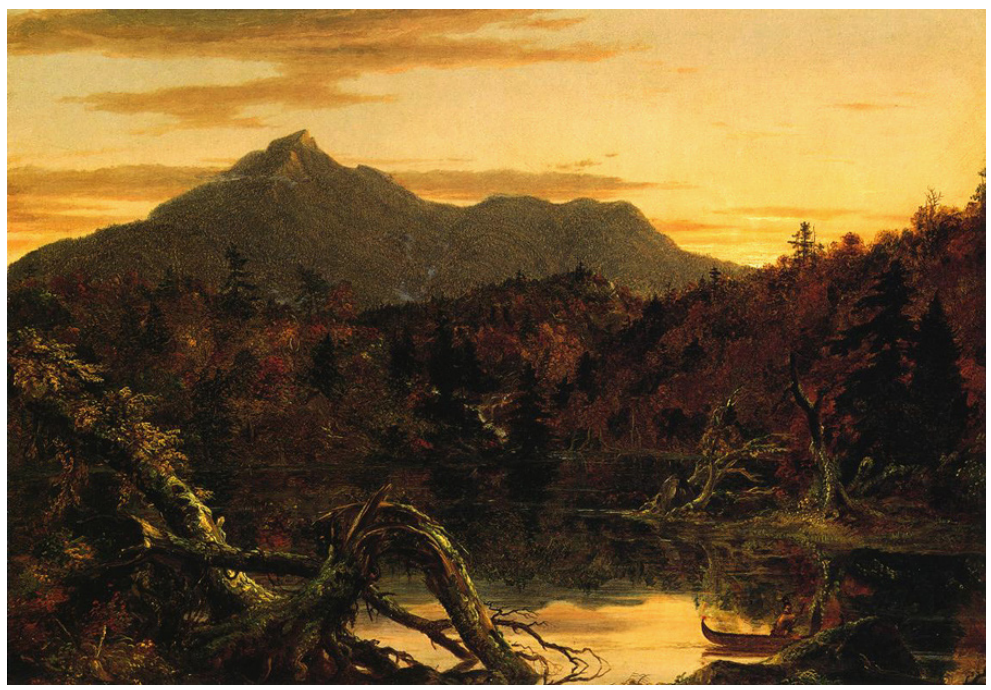

Fig. 10. Thomas Cole, Autumn Twilight, View of Corway Peak [Mount Chocorua], New Hampshire, New York Historical Society. 
Where Story described a "rustling" like "withered leaves of autumn," other comparable images proliferate, employed in a variety of period texts to illustrate the disappearance of Indians. "They've vanished, they have fled," like "the shades when the dawn is red" or like "the evanescent flush of twilight on the lake" or "like snow-flakes in the stream" in the work of Isaac McLellan. For Charles Sprague, Indians "slowly and sadly ... climb the distant mountains, and read their doom in the setting sun. They are shrinking before the mighty tide which is pressing them away; they must soon hear the roar of the last wave, which will settle over them forever." Natives were doomed "as the snow melts before the sunbeam" or "like a promontory of sand, exposed to the ceaseless encroachments of the ocean, they have been gradually wasting away before the current of the white population which set in upon them from every quarter." According to William Tudor Jr., Natives had "dwindled into insignificance and lingered among us, as the tide of civilization has flowed, mere floating deformities on its surface, poor, squalid and enervated with intoxicating liquors," so that they "diminish and waste before" civilization "like snow before the vernal influence." Similarly, as early as 1819, Henry Clay employed what he called a "figure" drawn from the "sublime eloquence" of Indians that "the poor children of the forest," had been "driven by a great wave ... overwhelming in its terrible progress" from the Atlantic to the Rockies, leaving "remains of hundreds of tribes, now extinct." Even individual images of "brittle leaves" repeat; Eliza B. Lee's Naomi: or Boston Two Hundred Years Ago (1847), a novel of "forbidden" love between an Indian and a Euroamerican woman in Boston of the 1670s claimed, "One by one they perish, like the leaves of the forest that are swept away by the autumn winds; melancholy shrouds them; they die of sadness, and are effaced from the earth by an inexorable destiny." 26

In some instances landscapes are selected for both scenic beauty and association with Natives, Indian connections known, Natives invoked as an absence in these depictions. Schroon Mountain, painted by Cole in 1830 (at Cleveland), subject of several period canvases, was named for an unfortunate "Indian maiden," like many of her alleged counterparts in the Northeast killing herself in an "unfortunate" love affair with a Frenchman-the topography commemorating her suicide. Schroon

26 See Isaac McLellan, "The Lament of the Last of the Tribes," Southern Literary Messenger, vol. 11 (September 1845), 538-539; Charles Sprague, "American Independence: An Oration Pronounced before the Inhabitants of Boston, July 4, 1825," The Poetical and Prose Writings of Charles Sprague (Boston, 1851), 150-53; for image "as the snow melts before the sunbeam" see "North American Indians," Quarterly Review (London) XXXI (Apr. 1824) 108; Tudor, "An Address delivered to the Phi Beta Kappa Society, at their anniversary meeting at Cambridge," North American Review, 2 (1815), 19; for Henry Clay's remarks, see Annals of Congress, 15th Session, Jan. 20, 1819, 639; for "like a promontory," see Georgia Senator John Elliot, Feb. 25, 1825, Register of Debates in Congress, 18th Cong., 2nd sess., 9: 640. 
Lake may derive from Sca-ni-a-dar-roon, "a large lake," abbreviated to Scaroon and Schroon, a Mohawk word found in many older deeds of the lake region while at the same time Scarona was the name of "an Indian girl, who leaped over a precipice from her French lover, and was drowned." ${ }^{27}$ [Fig. 11]

Bash Bish Falls, tucked away in the southwest corner of Massachusetts near the state's borders with Connecticut and New York, is "the state's highest waterfall. ..." John F. Kensett several times painted Bash-Bish Falls of South Egrement, Massachusetts, where an "Indian maiden" married to a "chief" but unable to bear a child and deceived by an Indian "witch," threw herself into the Bash-Bill cascade, her horrified "lover" jumping into the falls to rescue her, both drowning.

This legend revolves around a beautiful

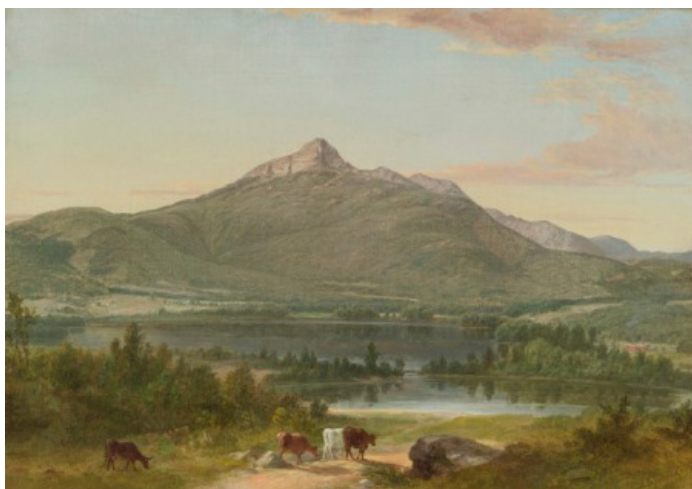

Fig. 11. Asher B. Durand, Mount Chocorua and Chocorua Lake from Tamworth, Private Collection. Mohican woman named Bash-Bish who was accused of this gravest of crimes, found guilty, and condemned to death as prescribed by tribal law, despite her persistent protestations of innocence. For the execution of her sentence, a canoe equipped with leather thongs was secured in the swift water upstream from a waterfall. Bash-Bish was to be bound to the vessel, which was then to be released and drawn by the current over the fateful cataract. At the appointed hour, the Indians, including the woman's infant daughter, White Swan, solemnly gathered for the ceremony. Suddenly a curious thing happened. A fine mist began to slant in from the sun while, simultaneously, a ring of bright butterflies circled Bash-Bish's head. As the Mohicans fell back in awe of the unexplained phenomenon, the condemned woman broke away, dashed to the edge of the falls and flung herself over the cruel shawl of water, the butterflies spiraling downward behind her. The pool below has never given up her body. To the Indians, this mysterious avoidance of punishment cast the woman in league with evil spirits and she was pronounced a witch, although her daughter was not likewise condemned but rather adopted by the tribe. White Swan grew to be as lovely as her mother

27 Alfred B. Street, The Indian Pass. (New York: Hurd \& Houghton, 1869), xvii. For other Native place name associations in the area, ibid., xii-xviii while Street details numerous other Indian legends in Woods and Waters or Summers in the Saranacs with Two Illustrations on Wood, (New York: Hurd \& Houghton, 1865). 
and in time married a handsome clansman, son of the ruling chief. They were a devoted couple, yet when White Swan was unable to bear her husband children, he, in keeping with tradition, took a second wife to give him an heir. Immediately, sorrow overwhelmed White Swan and she began to languish. She took to brooding on a crag above the falls, and even though her husband would bring her gifts and adornments of nuts and shells from the far-away sea, her dark melancholy increased. One night she dreamed Bash-Bish was beckoning her from beyond the waterfall, pleading with her to leave earthly woes behind and join her. To Mohicans, dreams proclaimed prophetic truth, and for the next few days White Swan never left the crag. Gazing down the long watery precipice to the blue-green depths below, she awaited her mother's next call. It came one evening just as her husband emerged from the forest bearing the most beautiful gift he could find, a pure white butterfly. Gently he spoke her name, but the enraptured girl did not hear. As he watched in horror, she suddenly plunged toward the falls, and as his hands flew open, the released butterfly followed White Swan's falling figure. In a vain attempt to save her, he too leaped into the water. The following day his broken body was found but there was not a trace of White Swan, now reunited forever with her mother behind the glittering waterfall. The site is now set aside as Bash-Bish State Forest where to this day the cascading water sometimes assumes the unmistakable shape of a woman and on moonlit nights a smiling female face may be seen beneath the surface of the pool below. (from Haunted New England, A Devilish View of the Yankee Past, Mary Bolte, Random House: New York, 1972)

Mount Chocorua, also known as Mount Corway, Corroway, or Carroway, in the Sandwich range of the White Mountains in New Hampshire is depicted with Native association in Cole's lost "Chocorua's Curse," known from an 1830 engraving. Chocorua was a seventeenth-century Indian whose dying curse either prevented crops from fully developing in the region or immigrants' cattle from flourishing - with original source materials ambiguous and contradictory, since the "curse" appears to be what mattered. As Cole recorded in his sketchbook/ diary for Oct. 3, 1828, following his second visit to Chocorua, the mountain's peak was associated with the Indian Chocorua, who had been chased to the summit by whites:

There they gave the poor despairing and defenseless wretch the cruel choice of whether he would leap from the dreadful precipice on the top of which he stood or die beneath their rifles. The ill-fated Chocorua refused to destroy himself by that terrible leap and suffered death beneath their hands. The country round the foot of Chocurua is inimical to raising cattle. Such as are taken there always die by an incurable disease. The superstition was alleged to a curse which Chocura is said to have uttered with dying lips that 'all the cattle of the white men brought onto his hunting ground should die. 
In a somewhat different version of the Chocorua legend, published four years after Cole's visit to the mountain, what was identified as "Chocorua's Cliff" was "particularly interesting by a legend which tradition has scarcely saved from oblivion," an anonymous author claiming, "Had it been in Scotland, perhaps the genius of Sir Walter would have hallowed it, and Americans would have crowded there to kindle fancy on the altar of memory," but "being in the midst of our own romantic scenery," Chocorua remained little known. ${ }^{28}$ [Fig. 12]

In this rendering, an actual Chocorua lived as whites began settling in southern New Hampshire, yet "from the Indians they received neither injury nor insult. No cause of quarrel had ever arisen; and, although their frequent visits were sometimes troublesome, they never had given indications of jealousy or malice." A "prophet among them," probably signifying a pow-wow or shaman, Chocorua was "an object of peculiar respect." Supposedly, he "had a mind which education and motive would have nerved with giant strength; but growing up in savage freedom,

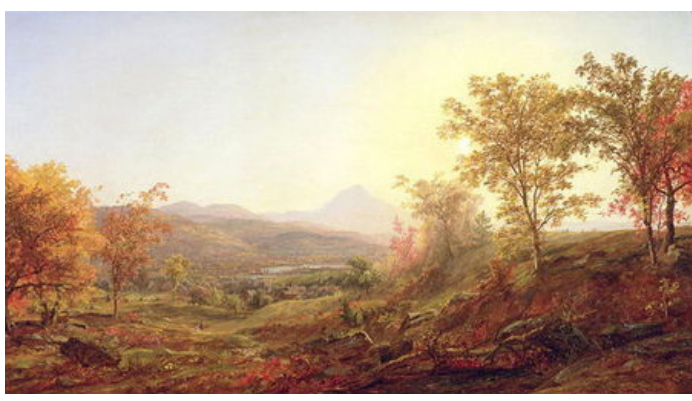

Fig. 12. Jasper Francis Cropsey, Autumn at Mount Chocorua, Brooklyn Museum, Brooklyn, New York.

it wasted itself in dark, fierce, ungovernable passions." About Chocorua, there was thus "something fearful in the quiet haughtiness of his lip-it seemed so like slumbering power, too proud to be lightly roused, \& too implacable to sleep again."

"In his small, black, fiery eyes, expression lay coiled up like a beautiful snake," so the "white people knew that his hatred would be terrible," so they "never provoked it, and even the children became too much accustomed to him to fear him."

Chocorua had a son, 9 or 10 years old, who frequented the house of a white family and "occasionally," received "gaudy presents as were likely to attract his savage fancy." The child became a "familiar visitant" at the family's house, until one day "being unrestrained by the courtesies of civilized life, he would inspect everything and taste of everything" including poison intended for a fox. Ill, the boy "went home to his father to sicken and die."

28 All Chocurua quotations from pamphlet, Anonymous, "Chocorua's Curse," in The Indian Fighter!! and Ghost of Morgan!!! Together with a great Variety of Other Tales, "To Amuse the Odd, the Comical and Queer." [S.1.: Rory Blare, 1832]. 
According to this narrative, "jealousy and hatred" took "possession" of Chocorua's soul, while he "brooded over them in secret, to nourish the deadly revenge" of killing the white woman he blamed for his son's death as well as her children. Pursued by the dead woman's husband to his cliffs, Chocorua was instructed to hurl himself from the precipice, to which he responded, "The Great Spirit gave life to Chocorua, and Chocorua will not throw it away at the command of a white man." As the man pointed his gun at Chocorua, the Indian "though fierce and fearless as a panther, had never overcome his dread of fire-arms. He placed his hand upon his ears to shut out the stunning report," still "the next moment blood bubbled from his neck, and he reeled fearfully on the edge of the precipice." Recovering and raising himself on his hands, "in a loud voice, that grew more terrific as its huskiness increased," Chocorua uttered:

A curse upon you ye, whiteman! May the Great Spirit curse ye when he speaks in the clouds, and his words are fire! Chocorua had a son and ye killed him while the sky looked bright! Lightning blast your crops! Wind and fire destroy your dwellings! The Evil Spirit breathe death upon your cattle! Your graces lie in the war path of the Indian! Panthers howl, and wolves fatten over your bones! Chocorua goes to the Great Spirit-

This version of the Chocorua story concludes, "the prophet sunk upon the ground, still uttering inaudible curses and they left his bones to whiten in the sun," but "to this day," Burton, New Hampshire is "remarkable for a pestilence which its cattle suffer"- the superstitious thinking "that Chocorua's spirit still sits upon his precipice breathing a curse upon them."

[Fig. 13]

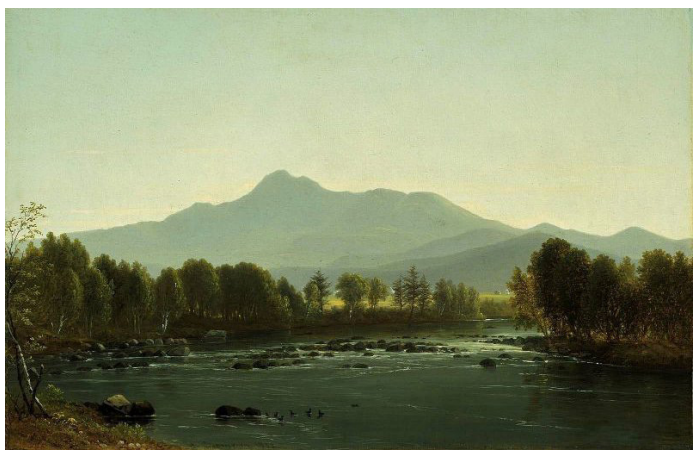

Fig. 13. Benjamin Champney, Mount Chocorua, 1858, Museum of Fine Arts, Boston. 
As other artists have painted the same location, however, the name "Chocorua" is apparently sufficient to evoke the "vanished" Indians of New Hampshire. Chocorua is like Mount-Saint-Victoire in Provence, painted and repainted by several French painters. Some of the more accessible versions include: "Chocorua's Curse" by Thomas Cole, 1830; and Chocorua by Asher Durand (1855), Aaron Draper Shattuck (1855), David Johnson (1851), Samuel Gerry (1861), Daniel Huntington (1861), and, J. F. Kensett (1864-66).

In these last works not only are Natives a vanishing people, but in their very vanishing they take on the presence of an absence. Indians here are, as they are not. They mediate between glorious, spiritualized landscapes and viewers; through their isolation, a white antebellum audience gains access to the fullness of nature. In each of these works it is longer necessary to depict Native Americans; in them text and image, together, re-inforce the notion of a people disappeared. They become part of a discourse of disappearing Indians. 


\section{Works Cited}

ADAMSON, Jeremy Ehwell. Niagara, Two Centuries of Changing Attitudes, 1697-1901. (Washington D.C. Corcoran Gallery of Art, 1993).

ANONYMOUS. A Landscape Book by American Artists and American Authors; Sixteen Engravings on Steel, from Paintings by Cole, Church, Cropsey, Durand Gignoux, Kensett, Miller, Richards, Smillie, Talbot, Weir (New York: G. P. Putnam \& Son, 1868)

ANONYMOUS. "The Indian Fighter!! and Ghost of Morgan!!! Together with a great Variety of Other Tales "To Amuse the Odd, the Comical and Queer." [S.1.: Rory Blare, 1832].

BAIGNELL, Matthew. "Territory, Race, Religion Images of Manifest Destiny," in Smithsonian Studies in American Art, vol. 4, no. 3-4 (Summer-Fall 1990).

BERKHOFER, Robert. Images of the American Indian from Columbus to the Present. (New York: Vintage Books, 2011).

BOLTE, Mary. Haunted New England, A Devilish View of the Yankee Past. ( New York: Random House, 1972).

BRYANT,_William Cullen. The American Landscape, No. 1 [shortened title] (New York: Elam Bliss, 1830).

CALLOW, James T. Kindred Spirits: Knickerbocker Writers and American Artists 1807-1855. (Chapel Hill: University of North Carolina Press, 1967).

CLAY, Henry. Annals of Congress, 15th Session, Jan. 20, 1819.

COLE, Thomas. "Essay on American Scenery," American Monthly Magazine, 1 (January 1836).

DIPPIE, Brian. The Vanishing American (University Press of Kansas: Revised Edition 1991).

DRAKE, Samuel G. Book of Indians. (Boston: Benjamin B. Massey, 1845).

ELLIOT, John. Register of Debates in Congress, 18th Cong., 2nd sess.

GALT, John. The Life of Benjamin West. Ed. Nathalia Wright, (Gainesville, Florida: Scholars' Facsimiles \& Reprints, 1960).

JACKSON, Andrew. "State of the Union speech." December 6, 1830.

LANE, Christopher W. Impressions of Niagra: The Charles Rand and Penn Collection of Prints of Niagra Falls and the Niagra River from the $16^{\text {th }}$ to the Early $20^{\text {th }}$ Century. (Philadelphia: Philadelphia Print Shop, 1993).

LUBLIN, David M. Picturing A Nation: Art and Social Change in Nineteenth-Century America. (New Haven: Yale University Press, 1994).

McKINSEY, Elizabeth R. Niagara Falls: Icon of the American Sublime, (New York: Cambridge University Press, 1985).

McLELLAN, Isaac. "The Lament of the Last of the Tribes," Southern Literary Messenger, vol. 11 (September 1845).

McNULTY, J. Bard, (ed.) The Correspondence of Thomas Cole and Daniel Wadsworth: Letters in the Watkinson Library, Trinity College, Hartford, and in the New York State Library, Albany, New York. (Hartford: Connecticut Historical Society, 1983).

SPRAGUE, Charles. The Poetical and Prose Writings of Charles Sprague (Boston, 1851 
221

STORY, Joseph. The Miscellaneous Writings, Literary, Critical, Juridical of Joseph Story LL.D. (Boston, 1835). STORY, William W., (ed.) Life and Letters of Joseph Story, Associate Justice of the Supreme Court of the United States and Dana Professor of Law at Harvard University, 2 vols. (Boston: Charles C. Little \& James Brown, 1851).

STREET, Alfred B. The Indian Pass. (New York: Hurd \& Houghton, 1869).

Woods and Waters or Summers in the Saranacs with Two Illustrations on Wood, (New York: Hurd \& Houghton, 1865).

TUDOR, William. "An Address delivered to the Phi Beta Kappa Society, at their anniversary meeting at Cambridge," North American Review, 2 (1815).

UNITED STATES GOVERNMENT PRINTING OFFICE, Art in the US Capitol Building. (United States, 1976). 


\section{LIST OF ILLUSTRATIONS}

Fig. 1. Tompkins Harrison Matteson, “The Last of the Race,” 1847, New-York Historical Society.

Fig. 2. From The Gentleman's Magazine, published in London in 1751.

Fig. 3. After Henry Fuesli, Vue de la Cascade du Niagara, en Amerique. dans le pais des Iroquois... engraving Pour le Voyage des quatre parties du Monde de M. Henri Vernon.

Fig. 4. An East View of the Great Cataract of Niagara, c. 1768, an engraving of Thomas Davies, Royal Ontario Museum, Toronto.

Fig. 5. Thomas Davies, Niagara Falls From Above, circa 1762-68.

Fig. 6. The Horseshoe Fall from Below Table Rock, attributed to John Vanderlyn.

Fig. 7. Alvan Fisher, A General View of the Falls of Niagara, 1820, Smithsonian American Art Museum, Washington, D.C.

Fig. 8. Sanford Robinson Gifford, Wilderness, view of Mount Chocurua, (1861), Toledo Museum of Art, Toledo, Ohio.

Fig. 9. Thomas Cole, Mount Chocorua, New Hampshire, 1827, Private Collection.

Fig. 10. Thomas Cole, Autumn Twilight, View of Corway Peak [Mount Chocorua], New Hampshire, New York Historical Society.

Fig. 11. Asher B. Durand, Mount Chocorua and Chocorua Lake from Tamworth, Private Collection.

Fig. 12. Jasper Francis Cropsey, Autumn at Mount Chocorua, Brooklyn Museum, Brooklyn, New York.

Fig. 13. Benjamin Champney, Mount Chocorua, 1858, Museum of Fine Arts, Boston. 